University of Nebraska - Lincoln

DigitalCommons@University of Nebraska - Lincoln

June 1987

\title{
The Political Business Cycle: An Institutional Critique and Reconstruction
}

Ann Mari May

University of Nebraska - Lincoln, amay1@UNL.edu

Follow this and additional works at: https://digitalcommons.unl.edu/cbafacpub

Part of the Business Commons

May, Ann Mari, "The Political Business Cycle: An Institutional Critique and Reconstruction" (1987). College of Business Faculty Publications. 19.

https://digitalcommons.unl.edu/cbafacpub/19

This Article is brought to you for free and open access by the Business, College of at DigitalCommons@University of Nebraska - Lincoln. It has been accepted for inclusion in College of Business Faculty Publications by an authorized administrator of DigitalCommons@University of Nebraska - Lincoln. 


\section{The Political Business Cycle: An Institutional Critique and Reconstruction}

Ann Mari May

John Maynard Keynes's General Theory provided the analytical framework and the rationale for using discretionary governmental policies to stabilize the economy at full employment. Although the Keynesian policy prescriptions continued to gain acceptance in the postwar period, the zenith of our confidence in the efficacy of stabilization policy was not reached until the mid-1960s. However, just as government intervention in the economy was becoming widely accepted, the familiar sound of ceremonial exhortations against governmental intervention again began to be heard ... this time in the area of stabilization policy.

One variant of the opposition to government intervention in the economy is the all too familiar monetarist attack. ${ }^{1}$ Another variant, which is more subtle but growing in importance, is embodied in the political business cycle literature. This literature argues that selfinterested politicians will manipulate the economy to enhance their reelection prospects, producing a boom and bust cycle. The government, according to this literature, is again the perpetrator of programs that destabilize, rather than stabilize, the economy.

It is in this light that the literature on the political business cycle warrants careful consideration and evaluation, for it can be seen as yet an-

The author is Instructor of Economics, Colorado State University, Fort Collins. This article was presented at the Annual Meeting of the Association for Evolutionary Economics, New Orleans, Louisiana, 27-30 December 1986. 
other argument for ceremonial laissez-faire doctrine in the area of stabilization policy. The purpose of this article is to examine the theoretical foundations of the current political business cycle literature and offer an alternative institutional framework of analysis. ${ }^{2}$ The institutionalist framework developed here allows us to identify the structural features of the economy that bring forth the political business cycle pattern of expansion and contraction, and to analyze the specific institutional factors that may prevent politicians from engaging in policies that result in the political business cycle pattern in a particular historical time period.

\section{The Evolution of Thought}

The literature on the political business cycle is currently dominated by public choice theorists who argue that self-interested politicians will manipulate the economy for political gain. However, the concept of the political business cycle has its origins in the writings of the Marxian economist, Michal Kalecki. ${ }^{3}$ Suspicious of the optimism of Keynes, Kalecki foresaw the continuation of the business cycle or, more correctly, the emergence of the political business cycle, not because the government was incapable of stimulating demand to alleviate unemployment, but because government officials would respond to political pressure from groups adverse to sustained full employment. ${ }^{4}$

In An Economic Theory of Democracy, Anthony Downs made explicit and legitimate an aspect of political behavior that Kalecki assumed implicity - that is, political actors are responsive to some segment(s) of the electorate. Assuming a more pluralistic model, Downs postulated that politicians compete for votes by responding to the demands of the electorate and are motivated to do so by selfinterest. ${ }^{5}$ Drawing explicit parallels with the neoclassical model of perfect competition, Downs postulated the existence of rational political actors attempting to maximize votes. Subsequent theories of the political business cycle, in somnambulant fashion, were drawn to the Downsian framework and incorporated this assumption of self-interested politicians into their analysis.

The theoretical foundation for the current literature, which I shall refer to as the orthodox approach to the political business cycle, was initially put forth by William Nordhaus. ${ }^{6}$ Nordhaus hypothesized a pattern of pre-election boom and post-election slump resulting from contractionary policies pursued in the initial years of an incumbent president's term, followed by expansionary policies pursued prior to 
the election. According to Nordhaus, the self-interested, votemaximizing president is constrained in manipulating the economy by the short-run Phillips Curve. The contractionary policies represent an attempt to reduce inflation and hence inflationary expectations, thereby shifting the short-run Phillips Curve downward. As the election approaches, expansionary policies are pursued to lower unemployment and exploit the short run trade-off between inflation and unemployment.

Subsequent studies of the presidential political business cycle have embraced Nordhaus's conceptual framework and have attempted to provide statistical evidence to support the hypothesis that presidents manipulate the economy to enhance their re-election prospects. Correlating time series data on economic activity with election years, these studies have produced conflicting evidence as to presidential manipulation of the economy. ${ }^{7}$

The literature on the political business cycle then, has attempted to analyze the relationship between the polity and the economy, however, both the Marxian and the current orthodox approach provide us with an explanation of this relationship that is uni-directional. Whereas Kalecki believed that the economic structure (class interests of the capitalists) controls the political structure, current studies assume that the political structure (politicians) manipulate and control the economic structure. I will argue that the relationship between the polity and the economy is more complex than these previous studies indicate. A more satisfying analysis of the political business cycle must acknowledge the interactive nature of this relationship between the polity and the economy by examining the institutional framework that affects politicians and their ability to manipulate the economy.

\section{Critique of the Orthodox Literature}

The current literature on the political business cycle is flawed on conceptual grounds by virtue of its neoclassical framework of analysis. The neoclassical approach is apparent in the assumption of human nature embodied in these studies as well as the ahistorical, ainstitutional nature of the analysis. In addition, the neoclassical framework prevents current studies from analyzing the structural features of the economy that make it necessary for politicans to engage in policies that produce the political business cycle pattern.

As previously stated, the orthodox approach hypothesizes that selfinterested politicians will manipulate the economy by engaging in con- 
tractionary policies in the early years of the presidential term and expansionary policies prior to the election. This hypothesis is problematic on several levels. First, the assumption of self-interest is excessively restrictive in that the existence of a president who behaves as an ideologue or caretaker of the public good is thus precluded. Although history has provided evidence of presidential behavior that conforms to the behavioral assumptions of the orthodox model, it is apparent that this self-interested behavior has not always emerged. ${ }^{8}$ Whereas the orthodox approach views presidential behavior as static and unchanging, a more realistic approach must view presidential behavior as malleable and culturally determined. Hence, a more useful theory of the political business cycle must focus not on the individual, but on the institutions that shape and determine the behavior of the individual.

Since few would argue that "the economic process is given effect in experience only through institutions," it seems incredible that a theory of the political business cycle would make no explicit mention of institutions and their impact on public policy. ${ }^{9}$ Yet, the orthodox approach is markedly ainstitutional and ahistorical. This inability of the orthodox approach to adequately deal with the institutional change has left several extremely important aspects of the political business cycle unexplained.

When effectuating policies that result in a political business cycle, the president has several policy tools available-changes in government spending, changes in taxes, indirect influence over monetary policy and, in rare circumstances, wage and price controls. ${ }^{10}$ It is necessary to note that none of these tools can be implemented by the president alone. For the president to stimulate the economy through changes in government spending or changes in taxes requires passage of bills by both Houses of Congress. For the president to influence monetary policy requires a Federal Reserve chairman who is not only sympathetic to the re-election goals of the president, but also capable of exerting the necessary power over the policy-making institutions of the Federal Reserve itself. ${ }^{11}$ Not only are these policy-making institutions ignored by the orthodox approach, but other important aspects of the operating environment of the president are ignored as well.

The president, when manipulating the economy for political gain, is susceptible to exposure by intra- and inter-party opposition candidates, as well as the press. If the press exposes expansionary policies as an attempt to manipulate the economy, the candidate's credibility as a caretaker of the public good may be adversely effected. Likewise, a can- 
didate engaging in expansionary policies prior to the election may be constrained by a more conservative opponent ready to criticize the policy as fiscally irresponsible. ${ }^{12}$

Finally, the orthodox approach, by virtue of its conceptual framework, can be viewed as yet another attempt to give ceremonial recognition to the failure of the governmental sector in order to revive our faith in laissez-faire. By arguing that the political business cycle is destabilizing and that it results from the rational behavior of selfinterested politicans, the solution becomes one of controlling politicians and limiting their involvement in the realm of stabilization policy. ${ }^{13}$ As such, the orthodox approach entirely avoids a discussion of the structural aspects of the economy that cause the political business cycle to be a recurrent feature of the economy.

\section{An Institutional Approach}

Whereas the orthodox approach views the political business cycle as emanating from self-interested, vote-maximizing politicians, the institutionalist framework developed here views the political business cycle pattern of boom and bust as an imperative of corporate capitalism. I will argue that the evolution of corporate capitalism has made periodic inflation a systemic feature of the economic environment, and that politicians must respond to the needs of the corporate sector by reducing inflation, but must also respond to the electorate by periodically reducing unemployment.

Not only is the orthodox approach misdirected as to the ultimate cause of the political business cycle, but it is insufficient in explaining the institutional constraints imposed on a president when attempting to fight unemployment prior to an election. In this section, we will identify and examine these institutional factors that impinge upon a president's ability to stimulate the economy prior to an election. We will also discuss the role that corporate capitalism plays in the political business cycle process.

In examining the institutional factors affecting the president's desire and ability to stimulate the economy prior to an election, the type of election must be recognized as an important determinant of presidential behavior. According to Edward Tufte, the incentive to stimulate the economy prior to the election is greater when the incumbent president is running than when he is not. ${ }^{14}$ Furthermore, the mid-term congressional election may be more important to the incumbent president 
than even the on-year election when the president is not seeking reelection; success at mid-term provides the opportunity for maintaining continuity of the president's programs. ${ }^{15}$

A second factor affecting a president's decision to attempt to implement policies consistent with the political business cycle is the perceived outcome of the election. Through opinion poll data, presidents have access to voter approval ratings and can determine their relative standing vis-a-vis opposing candidates. If the president perceives that the vote share is too small, the president is more likely to manipulate the economy to enhance his re-election prospects. However, if the president is virtually assured of victory, the incentive to manipulate the economy is diminished and ideological goals may be pursued.16

A third factor to consider concerns the probability that the activity will be detected or exposed to the public. This pressure of exposure has its origins in the media, an opposing party candidate, or a rival candidate within the president's own party. If the opposing candidates are relatively more conservative than the president, the chances for criticism and exposure for excessive spending are enhanced. With the press, risk of exposure would most likely depend upon the popularity of the president. A president who is perceived to be quite popular is less likely to receive scrutiny or criticism from the press than a less popular president. ${ }^{17}$

The ability of the president to expand the economy prior to the election will be determined by the president's ability to gain the cooperation of the Congress and the Federal Reserve. Concerning the role of Congress, it would appear that the probability of passing expenditure bills would increase if Congress was dominated by the party of the president. However, a Republican President facing a Democratic Congress may see this as the opportunity to implement some of the expansionary policies that may not have been possible at another time. ${ }^{18}$ For the president to manipulate the economy through monetary policy requires a Federal Reserve chairman who is not only sensitive to the re-election goals of the president but also capable of influencing the policy-making institutions of the Federal Reserve.

An examination of the presidential elections in the past twenty-five years reveals some interesting patterns that seem to support the points above. First, election returns do appear to be highly sensitive to economic conditions. In the three elections where real disposable income was rising at 4 percent or more in the election year, the incumbent party won [Table 1]. In the election years where real disposable income was growing at the lowest rates, 1960,1968, 1976, and 1980, the incumbent 
party lost. In addition, in the three elections since 1964 when the incumbent party lost, the incumbent party candidate was faced with an opposing candidate who was perceived to be more conservative. Finally, in the two elections since 1960 where the president was not seeking re-election, 1960 and 1968, real disposable income grew at a rate equal to or below the trend rate and the incumbent party lost.

Table 1. Total Real Disposable Personal Income: 1959-1984*.

\begin{tabular}{|c|c|c|}
\hline Year & $\begin{array}{c}\text { Total } \\
\text { (Billions of Dollars) }\end{array}$ & $\begin{array}{c}\text { Percentage } \\
\text { Change }\end{array}$ \\
\hline 1959 & $\$ 1,067.2$ & -- \\
\hline $\begin{array}{l}1960 \\
1961 \\
1962 \\
1963\end{array}$ & $\begin{array}{l}1,091.1 \\
1,123.2 \\
1,170.2 \\
1,207.3\end{array}$ & $\begin{array}{l}2.2 \\
2.9 \\
4.2 \\
3.2\end{array}$ \\
\hline $\begin{array}{l}1964 \\
1965 \\
1966 \\
1967\end{array}$ & $\begin{array}{l}1,291.0 \\
1,365.7 \\
1,431.3 \\
1,493.2\end{array}$ & $\begin{array}{l}6.9 \\
5.8 \\
4.8 \\
4.3\end{array}$ \\
\hline $\begin{array}{l}1968 \\
1969 \\
1970 \\
1971\end{array}$ & $\begin{array}{l}1,551.3 \\
1,599.8 \\
1,668.1 \\
1,728.4\end{array}$ & $\begin{array}{l}3.9 \\
3.1 \\
4.3 \\
3.6\end{array}$ \\
\hline $\begin{array}{l}1972 \\
1973 \\
1974 \\
1975\end{array}$ & $\begin{array}{l}1,797.4 \\
1,916.3 \\
1,896.6 \\
1,931.7\end{array}$ & $\begin{array}{r}4.0 \\
6.6 \\
-1.0 \\
1.8\end{array}$ \\
\hline $\begin{array}{l}1976 \\
1977 \\
1978 \\
1979\end{array}$ & $\begin{array}{l}2,001.0 \\
2,066.6 \\
2,167.4 \\
2,212.6\end{array}$ & $\begin{array}{l}3.6 \\
3.3 \\
4.9 \\
2.0\end{array}$ \\
\hline $\begin{array}{l}1980 \\
1981 \\
1982 \\
1983\end{array}$ & $\begin{array}{l}2,214.3 \\
2,248.6 \\
2,261.5 \\
2,334.6\end{array}$ & $\begin{array}{r}.0 \\
1.5 \\
.6 \\
3.2\end{array}$ \\
\hline 1984 & $2,468.4$ & 5.7 \\
\hline
\end{tabular}

Source: Council of Economic Advisers, Economic Report of the President 1986 (Washington, D.C.: U.S. Government Printing Office), p. 283. (Quarterly data at seasonally adjusted annual rates, 1982 dollars.)

The foregoing factors explain why a particular president may or may not be compelled to effectuate policies that produce a political business 
cycle. These factors also identify the constraints imposed on a president when attempting to stimulate the economy prior to an election. However, this does not explain the broader structural features of the economy that along with the instrumentally inadequate tools of stabilization policy, produce these periodic political business cycle episodes.

The growing concentration and consolidation of the business sector has been well documented elsewhere, however, the impact of this consolidation on the political business cycle has been neglected by the orthodox approach. ${ }^{19}$ As John Kenneth Galbraith has pointed out, the upward trend in prices is the result of the power of the planning system to set prices. ${ }^{20}$ The corporation, acting rationally in its own self-interest, sets prices as a mark up over costs, but collectively produces an outcome detrimental to the planning system as a whole-inflation. ${ }^{21}$ The planning sector then calls upon government to reduce inflation through contractionary policies. Historically, this contraction has been accomplished primarily through monetary policy which, as Galbraith has pointed out, does not affect the planning sector as much as the market sector. ${ }^{22}$ In this sense, the initial contraction of the political business cycle is not so much the result of manipulative politicans acting in their own self-interest, as politicians responding to the needs of the business sector. The expansionary policies that often, although not always, precede the election are merely the result of politicians who must respond to the needs of the electorate in an effort to reduce unemployment.

It may be argued of course that both the contractionary policies to fight inflation and the expansionary policies to reduce unemployment reflect attempts by policy-makers to respond to the needs of the electorate rather than of the business interests. However, I would argue that the business sector is at the forefront of the voracious attack against the so-called ravages of inflation that have actually benefited the lower and middle classes. ${ }^{23}$ This point is also buttressed by the studies on voter behavior that indicate that election outcomes are more sensitive to unemployment than to inflation. ${ }^{24}$

The institutionalist approach presented here argues that the political business cycle is a much more complex phenomenon than either the Marxian approach of Kalecki, or subsequent orthodox approaches indicate. In this analysis, the contraction phase of the cycle is the result of politicians responding to the needs of the corporate sector by reducing inflation, and the expansion phase, if circumstances require and permit, represents the politicians responding to the needs of the electorate by reducing unemployment. 
The study of the political business cycle is significant in that the orthodox approach merely provides another rationale for limiting the role of government in the area of stabilization policy. In contrast, the institutionalist approach views the political business cycle as an imperative of an economic system characterized by corporate capitalism where the dominant means of regulating economic activity are the moribund tools of traditional demand management policies. As a result, the solution to the problem of the political business cycle lies not in controlling self-interested politicians, as the orthodox approach would have us believe, but rather in recognizing the limitations of traditional stabilization policies in sustaining full employment without inflation, given the current structure of the economy.

\section{Notes}

1. Milton Friedman, A Program of Monetary Stability, (New York: Fordham University Press, 1960).

2. This article will primarily focus on the presidential political business cycle and not on congressional political business cycles.

3. Michal Kalecki, "Political Aspects of Full Employment," Political Quarterly (October/December 1943): 322-30.

4. Ibid., pp. 324-26.

5. Anthony Downs, An Economic Theory of Democracy (New York: Harper and Brothers, 1957).

6. William D. Nordhaus, "The Political Business Cycle," Review of Economic Studies 42 (April 1975): 169-90.

7. For example, see David G. Golden and James Poterba, "The Price of Popularity: The Political Business Cycle Reexamined," American Journal of Political Science, 24 (November 1980): 696-714, or Kevin J. Maloney and Michael L. Smirlock, "Business Cycles and the Political Process," Southern Economic Journal, 48 (October 1981): 377-92.

8. Robert R. Keller and Ann Mari May, "The Presidential Political Business Cycle of 1972," Journal of Economic History, 44 (June 1984): 265-71.

9. Marc Tool, The Discretionary Economy (Santa Monica, California: Goodyear Publishing Co., 1979) p. 73.

10. For a discussion of the influence of the president on monetary policy, see Sherman Maisel, Managing the Dollar (New York: Norton Publishing, 1973) pp. 108-13.

11. See Robert R. Keller and Ann Mari May, "The Presidential Political Business Cycle," p. 269.

12. Edward Tufte, Political Control of the Economy (Princeton, New Jersey: Princeton University Press, 1978), p. 54.

13. William Nordhaus, "The Political Business Cycle," p. 188.

14. Edward Tufte, Political Control of the Economy, p. 23-24.

15. Ibid., p. 23. 
16. Recognition of this aspect of the political business cycle has been built into some orthodox studies. For example, see Bruno S. Frey and F. Schneider, "An Empirical Study of Politico-Economic Interaction in the United States," Review of Economics and Statistics, 60 (May 1978): 174-83.

17. David Paletz and Robert Entman, Media Power Politics, (New York: Free Press, 1981) p. 69.

18. Edward Tufte, Political Control of the Economy, p. 54.

19. See John Munkirs, The Transformation of American Capitalism (New York: M.E. Sharpe Inc., 1985) and John Kenneth Galbraith, The New Industrial State (Boston: Houghton Mifflin Co., 1985).

20. John Kenneth Galbraith, Economics and the Public Purpose (Boston: Houghton Mifflin, 1973) p. 186-91.

21. Joseph J. Minarik, "Who Wins, Who Loses From Inflation," The Brookings Bulletin, 15 (Summer 1978): 6-10, esp. p. 7.

22. John Kenneth Galbraith, "Market Structure and Stabilization Policy," Review of Economics and Statistics 39 (May 1957): 124-33.

23. Joseph J. Minarik, "Who Wins, Who Loses From Inflation," pp. 8-9.

24. See Ray C. Fair, "The Effects of Economic Events on Votes For President," The Review of Economics and Statistics 60 (May 1978): 159-73. 